\title{
Methods and Rates of Punishment Implemented by Families to Enuretic Children in Turkey
}

\author{
M. Ihsan Karaman, Orhan Koca, Eyup Veli Kucuk, Metin Ishak Ozturk, Mehmet Akyuz \\ Department of Urology, Haydarpasa Numune Training and Research Hospital, Istanbul, Turkey
}

\section{ABSTRACT}

Purpose: Nocturnal enuresis is a serious health problem affecting a significant portion of the population. In this study, we investigated the frequency of punishment methods in nocturnal enuresis (NE) in Turkey and its relationship with other parameters.

Materials and Methods: A total of 501 children (301 boys and 200 girls) who were admitted to our outpatient clinic due to nocturnal enuresis were included in the study. Mean age was 9.39 years (range 5-18). Prepared questionnaire form inquiring educational status of the family, frequency and implementation and duration of punishment methods was applied to patients and families.

Results: At least one punishment method was applied to 291 (58.1\%) of children with NE. Punishment methods of parents were detected as condemnation (257 patients, 51.3\%), depriving desires of the child (120 patients, 23.9\%), humiliating the child in the presence of other children (113 patients, 22.6\%), reprimanding- threatening with punishment (203 patients, 40.5\%). This application was found to continue for longer than 1 year in 52\% of punished children. Families graduated of high school and above were found to use punishment methods significantly more than others.

Conclusion: According to the results of our study, a quite high proportion of enuretic children were detected to be exposed to punishment methods. Even, some parents consider that these methods are a part of nocturnal enuresis treatment. We, the doctors, should endeavor more for raising awareness of the community in order to diminish this worrisome behavior.

\section{ARTICLE INFO}

\section{Key words:}

Nocturnal Enuresis;

Punishment; Education; Child

Int Braz J Urol. 2013; 39: 402-7

Submitted for publication:

April 10, 2012

Accepted after revision:

February 04, 2013

\section{INTRODUCTION}

Enuresis is synonymous to intermittent nocturnal incontinence in discrete episodes while asleep. Monosymptomatic nocturnal enuresis is a symptom and a condition without any other lower urinary tract symptoms (LUTS) and without a history of bladder dysfunction (1).

Monosymptomatic nocturnal enuresis is a symptom rather than a disease and a severe health problem affecting a significant proportion of the community. Approximately 15\% of children aged 5 years still have night-wetting and these complaints improve 15\% each year (2). In the studies conducted in our country, NE was found in varying incidences between 11.5-19.03\% $(3,4)$. Maturation deficiency in central nervous system development, stress affecting the child especially between 2-4 years, depth of sleep, genetic and rarely organic factors play roles in etiology of enuresis (5). A variety of treatment methods are tried in nocturnal enuresis. Every physician or medical center may have different therapy protocols differing according to the patient and the family. 
Behavioral therapies, medical treatments, enuretic alarm devices are some of these methods.

Reactions of the families differ against this condition which concerns such a great majority of the community and leads to various social and psychological problems. Parents try different treatment methods in order to solve this problem by themselves. Threatening and punishing the child is one of these treatment methods (6). In this study, we investigated the frequency of punishment methods implemented in nocturnal enuresis and their relationship with other parameters.

\section{MATERIALS AND METHODS}

A total of 501 children (301 (60\%) boys and 200 (40\%) girls) who were admitted to our outpatient clinic with nocturnal enuresis for the first time and detected to have nocturnal enuresis (NE) as the result of evaluations were included in the study, in a period of three years.

Questionnaire forms prepared for this purpose were filled out by the families of children who complaint of nocturnal enuresis (Table-1). Parental education level, applied punishment methods and frequency and duration of application were inquired with this questionnaire. Depriving of desires of the child, humiliating the child in the presence of other children, reprimanding-threatening with $\mathrm{pu}-$ nishment were accepted as mild punishment methods, depriving of sleep, searing the child's penis, leaving the child wet, locking up in the room or the house, mildly beating, beating with hands or a bat were grouped as severe punishment methods. This discrimination was made mainly on cultural features other than scientific data. All forms were given to the mother or the father with closed envelopes and asked to fill at home or in the hospital by themselves. Questionnaire forms of the illiterate parents were filled out by their relatives by asking to them.

Spearman correlation and chi-square test were used for statistical analysis. A p value of $<0.05$ was accepted as statistically significant.

\section{RESULTS}

A total of 501 children (301 boys-60\% and 200 girls-40\%) with mean age of $9.39 \pm 3.58$ ye- ars (range 5-18) who were admitted to outpatient clinic with complaint of nocturnal enuresis were evaluated in our study.

At least one punishment method had been applied to 291 (58.1\%) children with NE. Of these children, 153 (30.5\%) were exposed to at least one severe punishment method. Punishment methods were condemnation in 257 patients (51.3\%), depriving of the desires of the child in 120 patients (23.9\%), humiliating the child in the presence of other children in 113 patients (22.6\%), reprimanding-threatening with punishment in 203 patients (40.5\%), depriving of sleep in 17 patients (3.4\%), searing the child's penis in 5 patients (1\%), leaving the child wet in 29 patients (5.8\%), locking up in the room or the house in 26 patients (5.2\%), mildly beating in 63 patients (12.6\%), beating with hands or a bat in 77 patients (15.4\%) (Table-2).

This punishment method was continued for longer than 1 year in 52\% of children, between 6 months and 1 year in 14\%, shorter than 6 months in 20\% and only for a few times in 14\%. Parents stated that they applied these punishment methods constantly to $24.2 \%$ of children and sometimes to $75.8 \%$ of children. 195 of parents (38.9\%) used punishment in order to cease NE, on the other hand 96 of parents (19.2\%) used punishment just for punishing the behavior.

When educational status of mothers was analyzed, it was seen that while 22 (4.4\%) were graduates of college, $133(26.5 \%)$ were graduates of high-school, $22(4.4 \%)$ were graduates of intermediate school, 291 (58.1\%) were graduates of elementary school, $33(6.6 \%)$ were illiterate. Educational status of fathers was as follows: 100 $(20 \%)$ were graduates of college, 158 (31.5\%) were graduates of high school, 26 (5.2\%) were graduates of intermediate school, 203 (40.5\%) were graduates of elementary school, $14(2.8 \%)$ were illiterate (Table-3). If at least one parent was high school graduated or above, It was seen that application of punishment methods were more frequent compared to others $(p=0.018)$ (Table-2). Maternal education level was found to be correlated more significantly than paternal educational level $(\mathrm{p}<$ 0.038). However, it was seen that while parents who were high school graduates or above applied mostly mild punishment methods, parents whose 
Table 1 - Questionnaire for nocturnal enuresis.

\section{1 - How old is your child?}

2 - What is your child gender?
a) Boy
b) Girl

3 - Did you use any punishment method because of nocturnal enuresis?
a) Yes
b) No

\section{4 - What kind of punishment method did you use?}
a) condemnation
b) depriving of the desires of the child
c) depriving of sleep
d) reprimanding-threatening with punishment
e) searing the child's penis
f) humiliating the child near others
g) leaving the child wet
i) locking up in the room or the house
j) mildly beating
k) beating with hands or a bat Other

\section{5 - How often did you use this punishment method?}
a) sometimes
b) constantly

\section{6 - How long did you use this punishment method?}
a) only for a few times
b) shorter than 6 month
c) 6 months- 1 year
c) longer than 1 year

7 - Why did you use this punishment method?
a) in order to treat
b) in order to punish

8 - What is the educational status of the mother:
a) illiterate
b) elementary school
c) intermediate school
d) high-school graduated
e) college graduated

\section{9 - What is the educational status of the father?}
a) illiterate
b) elementary school
c) intermediate school
d) high-school graduated
e) college graduated 
Table 2 - Distribution of punishment methods implemented by parents.

\begin{tabular}{|c|c|c|c|c|c|}
\hline & & $\begin{array}{l}\text { *high school and } \\
\text { above (N:281) }\end{array}$ & $\begin{array}{c}{ }^{* \star} \text { low } \\
\text { educational } \\
\text { status (N:220) }\end{array}$ & $P$ & Total \\
\hline \multirow{4}{*}{$\begin{array}{l}\text { Mild punishment } \\
\# 139(27.9 \%)\end{array}$} & Condemnation & $153(30.5 \%)$ & $104(20.8 \%)$ & 0.012 & $257(51.3 \%)$ \\
\hline & $\begin{array}{l}\text { Depriving of the desires of the } \\
\text { child }\end{array}$ & $73(14.6 \%)$ & $47(9.4 \%)$ & 0.028 & $120(23.9 \%)$ \\
\hline & Humiliating the child near others & $55(10.0 \%)$ & $68(13.6 \%)$ & $>0.05$ & $113(22.6 \%)$ \\
\hline & $\begin{array}{c}\text { Reprimanding-threatening with } \\
\text { punishment }\end{array}$ & $123(24.6 \%)$ & $80(16.0 \%)$ & 0.042 & $203(40.5 \%)$ \\
\hline \multirow{6}{*}{$\begin{array}{l}\text { Severe } \\
\text { punishment } \\
\# \# 152(30.2 \%)\end{array}$} & Depriving of sleep & $9(1.8 \%)$ & $8(1.6 \%)$ & $>0.05$ & $17(3.4 \%)$ \\
\hline & Leaving the child wet & $15(3.0 \%)$ & $14(2.8 \%)$ & $>0.05$ & $29(5.8 \%)$ \\
\hline & $\begin{array}{c}\text { Locking up in the room or the } \\
\text { house }\end{array}$ & $9(1.8 \%)$ & $17(3.4 \%)$ & 0.038 & $26(5.2 \%)$ \\
\hline & Mildly beating & $29(5.8 \%)$ & $34(6.8 \%)$ & $>0.05$ & $63(12.6 \%)$ \\
\hline & Beating with hands or a bat & $15(3.0 \%)$ & $62(12.4 \%)$ & $<0.001$ & $77(15.4 \%)$ \\
\hline & Searing the child's penis & $0(0 \%)$ & $5(1.0 \%)$ & $\mathrm{a}$ & $5(1 \%)$ \\
\hline
\end{tabular}

a: Statistical analysis was not performed in the patients because of the small number of patients

*: Families with at least one parent is high school graduated and above

${ }^{* *}$ : Families that both parents are graduated of intermediate school and lower

\#: Exposed to no severe punishment method

\#\#: Exposed to at least one severe punishment method

Table 3 - Educational status of parents (percent).

\begin{tabular}{lccccc}
\hline & Illiterate & Elementary school & $\begin{array}{c}\text { Intermediate } \\
\text { school }\end{array}$ & High school & College \\
\hline Mother & $33(6.6 \%)$ & $291(58.1 \%)$ & $22(4.4 \%)$ & $133(26.5 \%)$ & $22(4.4 \%)$ \\
Father & $14(2.8 \%)$ & $203(40.5 \%)$ & $26(5.2 \%)$ & $158(31.5 \%)$ & $100(20 \%)$ \\
\hline
\end{tabular}

educational level was lower applied more severe punishment methods.

There were no statistically significant relation between sex of children, method of punishment, duration and frequency of punishment.
While there was no statically significant relation between age of children and mild punishment methods ( $p>0.05)$, severe punishment methods were significantly more frequent for children aged 12 or older $(\mathrm{p}=0.028)$. 


\section{DISCUSSION}

NE is bed wetting of a child with no bladder dysfunction and other lower urinary tract symptoms who is expected to be continent by his or her age and neurological development (7). NE has negative effects on both child and parents. This situation creates serious stress on family and causes loss of self confidence of child (5). Reactions of families to this condition which concerns vast majority of society and causing psychological problems may differ in many ways. Parents try to solve this situation with different methods on their own.

Expectations of parents about bed-wetting and its treatment differ from those of the doctors. Unfortunately, the most common punishment methods includes behavior models towards punishment and humiliating the child in the presence of other people throughout history. In a study, one-third of American families who have enuretic children were emphasized to exhibit punitive attitudes (8). In the study of Ouédraogo et al. carried out in France, they reported that 27\% of families punished their enuretic children (6). In our study, 58\% of families applied at least one punishment method to their children. $24.2 \%$ of the families that applied punishment methods reported that this was done constantly. It should be kept in mind that application of these punishment methods could lead to guilt and reduction in self-confidence in children.

In a study of Byrd et al., it was reported that when alarm device was used due to failure of other methods, awakening and disturbance of other family members besides the enuretic child could increase the punishment of the child and physical abuse (8). In the study of Redsell et al., they reported that tolerance level of mothers of enuretic children was lower (9). In the study of Can et al., they detected child abuse in $86.4 \%$ of enuretic children (4). Incidence of spanking were found to be $42.1 \%$ in the these families. In our study, parents of children with PMNE applied punishment methods more as education measure. Possible reason for this condition was considered to be lower endurance of parents.
In a study of Butler et al., they stated that parents of enuretic children can be extremely guarding and even some of them could be angry and prefer punishment for coping with enuresis (10). In the study of Sapi et al., they stated that all of enuretic children were exposed to domestic violence and detected physical punishment in 48.5\% (11). In our study, 30\% of families who applied punishment methods exhibited behaviors that could lead to severe psychological and physical traumas like beating the enuretic child. Searing the child's penis (1\% of children with NE) in our study is a quite thought-provoking and unacceptable condition. It is a known reality today that punishing is wrong and rewarding is a more appropriate approach. Additionally, behavioral methods, medical treatments, acupuncture and hypnotherapy-like methods which are still in investigation phase are gradually gaining importance as our knowledge about etiopathogenesis of nocturnal enuresis increases $(12,13)$.

Our study has some limitations. First of all, it is a single-center study and we did not question the severity of NE. Selecting the sample from parents who referred to hospital and omitting the others who didn't seek any help for this problem is another limitation. Also we didn't question whether or not the parents have any previous the experience about NE.

The first and the most important step in treatment of enuresis is motivating the child for treatment and you need to empathize with the child, provide the understanding and support of the family, assure that the problem will be solved to achieve this.

\section{CONCLUSIONS}

According to the results of our study, a quite high proportion of children were exposed to punishment methods. Even some parents consider that these methods are a part of NE treatment. Definitely a large part of these results arise from insufficient knowledge. However, an interesting data of our study is that punishment rates increased as educational level of parents increased. While mild punishments were preferred by the parents who 
have high educational level, families with lower educational status preferred severe punishment methods. Informing only the parents who apply to outpatient clinic is not sufficient for raising awareness of the community in order to reduce the trauma that the children are exposed to. Since it is not possible for all children with NE to be treated by health institutions, other means (media etc.) should be tried to create awareness not to use punishment to heal NE by parents.

\section{CONFLICT OF INTEREST}

None declared.

\section{REFERENCES}

1. Nevéus T, von Gontard A, Hoebeke P, Hjälmås K, Bauer S, Bower $\mathrm{W}$, et al.: The standardization of terminology of lower urinary tract function in children and adolescents: report from the Standardisation Committee of the International Children's Continence Society. J Urol. 2006; 176: 314-24.

2. Ramakrishnan K: Evaluation and treatment of enuresis. Am Fam Physician. 2008; 78: 489-96.

3. Serel TA, Akhan G, Koyuncuoğlu HR, Oztürk A, Doğruer K, Unal S, et al.: Epidemiology of enuresis in Turkish children. Scand J Urol Nephrol. 1997; 31: 537-9.

4. Can G, Topbas M, Okten A, Kizil M: Child abuse as a result of enuresis. Pediatr Int. 2004; 46: 64-6.

5. National Clinical Guideline Centre (UK): Nocturnal Enuresis: The Management of Bedwetting in Children and Young People. London: Royal College of Physicians (UK); 2010.
6. Ouédraogo A, Kere M, Ouédraogo TL, Jesu F: Epidemiology of enuresis in children and adolescents aged 5-16 years in Ouagadougou (Burkina Faso). Arch Pediatr. 1997; 4: 947-51.

7. Hjalmas K, Arnold T, Bower W, Caione P, Chiozza LM, von Gontard A, et al.: Nocturnal enuresis: an international evidence based management strategy. J Urol. 2004; 171: 2545-61.

8. Byrd RS, Weitzman M, Lanphear NE, Auinger P: Bed-wetting in US children: epidemiology and related behavior problems. Pediatrics. 1996; 98: 414-9.

9. Redsell SA, Collier J, Garrud P, Evans JH, Cawood C: Multimedia versus written information for nocturnal enuresis education: a cluster randomized controlled trial. Child Care Health Dev. 2003; 29: 121-9.

10. Butler RJ: Annotation: night wetting in children: psychological aspects. J Child Psychol Psychiatry. 1998; 39: 453-63.

11. Sapi MC, Vasconcelos JS, Silva FG, Damião R, Silva EA: Assessment of domestic violence against children and adolescents with enuresis. J Pediatr (Rio J). 2009; 85: 433-7.

12. Karaman MI, Koca 0 , Küçük EV, Öztürk M, Güneş $M$, Kaya C: Laser acupuncture therapy for primary monosymptomatic nocturnal enuresis. J Urol. 2011; 185: 1852-6.

13. von Gontard A: Annotation: day and night wetting in children-a paediatric and child psychiatric perspective. J Child Psychol Psychiatry. 1998; 39: 439-51.

Correspondence address: Dr. Orhan Koca

Department of Urology

Haydarpasa Numune Training and Research Hospital Tibbiye cad. no:2 Üsküdar, 34718, Istanbul, Turkey

Fax: + 90216 345-5982

E-mail: drorhankoca@hotmail.com 